\title{
Does the Energy-Food Nexus still exist: Empirical Evidence from the Indian Agriculture Sector post food crisis of 2006
}

\author{
Effulgence \\ Vol. 18, No. 2 \\ July - December, 2020 \\ Rukmini Devi Institute of Advanced Studies \\ E-mail : effulgence@rdias.ac.in, Website : www.rdias.ac.in \\ http://effulgence.rdias.ac.in/user/default.aspx \\ https://dx.doi.org/10.33601/effulgence.rdias/v18/i2/2020/13-27
}

\author{
Dr. Rakesh Shahani ${ }^{1} \bowtie$ \\ Mr. Shikshu Kumar ${ }^{2}$ \\ Ms. Anusha Goel ${ }^{3}$
}

\begin{abstract}
The present study made an attempt to empirically investigate the impact of crude oil prices on agricultural prices for India during the calendar decade 2010-19. The bio-fuels which were considered in the present study included soy-oil, rapeseed oil, sunflower oil and palm-oil. The study covered a period of post food crisis of 2006 and after three years of stabilization of these prices to get an insight into the current scenario. The econometric tools used to examine the relationship included Johansen Cointegration, Gregory Hansen Co-integration with structural breaks, Toda and Yamamoto Causality and GARCH $(1,1)$ Method. The results of our study did not give sufficient evidence to prove that crude oils impacted any of the bio-fuel prices in current scenario. The long run inter-linkages between crude oil and energy crops was not established which brought us to the conclusion that the energy-food nexus was a temporary phenomenon that existed during food crisis (2006) only and crude prices were no longer a guiding force to determine the price of bio-fuels.
\end{abstract}

Keywords: Bio-fuels, Co-integration, Structural Break, Causality, Spill-over.

\section{INTRODUCTION}

$\mathrm{I}^{\mathrm{t}}$ is often said that crude prices and prices of agriculture products go hand in hand. This may not be true for each and every agricultural product, but the relation holds for quite a significant number of agricultural products as proved in most research studies. The relation between movement of crude and agricultural products can be studied from three

1. Associate Professor, Department of Business Economics, Dr. Bhim Rao Ambedkar College, University of Delhi, rakesh.shahani@gmail.com

2. Student Researcher, BA (H) Business Economics, Dr. Bhim Rao Ambedkar College, University of Delhi, shikshu24@gmail.com

3. Assistant Professor, Department of Management Studies, Shaheed Sukhdev College of Business Studies, University of Delhi, anusha.goel92@gmail.com 
different angles. To put in a different way, there are three possible routes by which energy can impact prices of agricultural products; first, when energy prices are high, it is quite obvious that products obtained from it like fertilizers, pesticides and chemicals also see an upward rise. Since fertilizer is an essential input to agriculture, this in turn pushes up agricultural cost of production leading to rise in the prices of agricultural commodities, second; with the rise in energy prices, transportation costs also rise, which further contributes to increase in production costs of agricultural commodities (Fowowe, B. 2016) and the final route is: the rise in demand for bio-fuels* encourages farmers to shift to plantation of crops which are used in producing these bio-fuels. Its production is further enhanced because of subsidies offered by the government (Fowowe, B. 2016). It is important to add here that one of the reasons which lead to the food crisis in 2006 was that many governments starting following separate policies for biofuels for which they also had to face a lot of criticism.( Nazlioglu, S., Erdem, C., and Soytas, U. 2013). Moreover, government subsidies which were helpful in reducing cost of production of biofuels did not actually translate to reduction in final price of biofuels and this was mainly because demand for these biofuels always remained high irrespective of their prices. Further many research studies have proved that the prices of the energy crops had actually highly intensified especially after the introduction of biofuels.

Coming back to exploring the relation between crude and agricultural products, although a large number of research studies have found a positive relation between the two, there are few studies have also found negligible or no relation between them. A popular study in this direction has been by Fowowe, B. (2016) who found no evidence for long-run relationship between crude prices and agricultural prices in case of South Africa. Another popular research in this area has been given by Cashin and McDermott (2001) where they analyzed the problem from a different dimension. Considering a bigger time frame of 140 years, they found that the prices of commodities had actually witnessed a downfall by approximately $1 \%$ p.a. while the volatility in agricultural commodities had risen during the same period. This heightened volatility had strong impact on country's terms of trade, current account and growth rates especially for those which were highly dependent on these commodities.

It is important to note that the food-energy nexus has been one of the prominent research areas during food crisis period of 2006. A number of studies have been conducted to understand the energy - food dynamics and some prominent studies have been discussed in great detail in section 2 under review of literature.

Considering the above, the present study makes an attempt to empirically investigate the impact of crude oil prices on agricultural prices for India during the calendar decade 2010-19. The bio-fuels which have been considered in the present study include soy-oil, rapeseed oil, sunflower oil and palm-oil and the monthly spot closing prices of these biofuels have been obtained from the website www.indexmundi.com. Since the price of crude is determined at the international level, the present study would suggest whether the global crude oil prices are responsible for rise in domestic agricultural prices and to what extent. An important aspect of this study is to examine the relation between crude and energy crops post the food crisis of 2006. Moreover the study covers the period of Jan 2010-Dec 2019 when crude prices were more or less stabilized in international markets. Hence the present research would enable us to confirm whether the energy-food nexus was a temporary phenomenon or still exists as a perennial problem.

* Biofuels, also called energy crops are fuels mainly produced from plants and are added to diesel or gasoline as additives to reduce the emissions. The crops acting as main source for bio-fuel include corn, sugarcane, soybean and some oils. (www. Wikipedia.com) 
The rest of the paper is structured as follows: Section 2 reviews the existing work done in the area of interlinkages between crude oil and agriculture products. Section 3 discusses the research objectives and methods used in the study. Section 4 gives the distribution characteristics of our variables. Section 5 gives the methodology employed along with hypothesis to be tested. The next section, Section 6 provides empirical results of the study. Section 7 gives the conclusion and policy implications followed by references in Section 8 and appendices in Section 9.

\section{REVIEW OF LITERATURE}

Quite a significant number of research papers have focused on linkages between two important segments of commodity markets viz. energy and agriculture (or the food-energy nexus) in twenty first century. As previously discussed, rising interest in this area is mainly because the world had witnessed a simultaneous surge in prices of oil and agricultural commodities during the decade 2000-2010. The oil prices had reached a peak of $\$ 145$ a barrel in July 2008 and a similar trend was seen in agricultural prices such that everybody started blaming biodiesel prices for rise in prices of the related agricultural inputs (although most research studies proved it otherwise) and this surge continued till the occurrence of global financial crisis in 2008 (Fowowe, B. 2016). Some of important papers in this area along with their key findings are discussed under this section.

Some of the studies to explore the linkages between energy and agriculture include a study by AbdulRahim, A. S., \& Zariyawati, M. A. (2011) whereby they used ARDL approach to test the co-integrating relation between crude and two agricultural commodities namely rice and soybean oil using time series annual data from 1970 to 2008. The results showed that in the long term, crude impacted rice but not soybean oil. On the other hand in the short run, the prices of world crude oil were not found to be impacting both these prices viz. rice and soybean oil. Another study published in the same year was carried out by Nazlioglu, S., \& Soytas, U. (2011) where they investigated for Turkey using monthly data from Jan 1994- March 2010 the impact of crude prices on various agricultural commodities and found that in both short and long run there was no impact of world crude prices on agricultural prices.

Similar results, but using a different methodology were reported by Cabrera, B. L., \& Schulz, F. (2016) whereby they studied linkages between returns and variability in prices of agricultural commodities and energy prices using multivariate GARCH Model and multiplicative volatility model. The monthly prices of rapeseed oil, biodiesel and crude were used in the study and study concluded that biodiesel did not seem to influence rapeseed in the short run, further a weak linkage was seen between volatility of biodiesel \& volatility of crude oil and rapeseed. Thus results revealed that biodiesel was not responsible for high agricultural prices and also did not impact volatility of the agricultural prices. During the same year, another study was undertaken by Fowowe, B. (2016) who investigated the impact of rise in crude prices on agricultural commodities for South Africa using Gregory-Hansen co-integration with structural breaks. This study too found no evidence of a longrun relationship between crude prices and agricultural prices. For testing causality, the study employed non-linear causality tests and its results too showed that causality was not moving from oil to agricultural prices. The conclusion was that agricultural prices were neutral to crude prices in South Africa.

On the other hand, few researchers could find a relation between crude and agro based energy products and one such study was carried out by Mitchell (2008) who estimated that bio-fuels, directly or indirectly were responsible for $70 \%$ of rise in international food prices during the period 2006-08. In another study, Yang et al. (2008) explained how $77 \%$ of the rise in the price of maize and $66 \%$ rise in soybean price in U.S. was due to energy-related factors during the period 2005-08. A study by 
Zafeiriou, E., et.al. (2018) examined the twin relationships of crude oil-corn and crude oil-soybean using ARDL co-integration framework. The results too confirmed that crude prices were impacting agricultural prices especially prices of crops used as bio-fuels in the energy industry. A noteworthy research study in this area was carried out by Bakhat, M., \& Würzburg, K. (2013) who applied threshold co-integration analysis to study the linkages between movement of crude and agricultural commodities, they found that there was asymmetry in adjustments to long run equilibrium in terms of both positive and negative deviations in the short run for different commodities and therefore they concluded that the adjustment mechanism between oil and commodities was highly complex and therefore required both linear and non-linear investigations. Based upon these recommendations, researchers started working on non-linear based models and one such study was carried out by Rafiq, S., \& Bloch, H. (2016) where the researchers investigated both short and long run linkages to test the impact of oil on other agricultural commodities using linear and non -linear models. The data period of the study was extensive and covered a period from 1900 to 2011.The methodology included ARDL \& Non Linear ARDL (NARDL) co-integration models \& test for Causality (both Granger and Non Linear). The results of the study confirmed the presence of non-linearity between oil and a large no. of commodities. Further the asymmetric Granger results indicated that a decline in oil prices caused a negative impact on 13 commodity prices, while a positive shock resulted in an increase in prices of only 3 commodities.

Similar attempt in the direction of testing non-linear relation was carried out by Zmami, M., \& Ben-Salha, O. (2019) where they investigated using linear and non linear ARDL technique, the long term cointegration between prices of agricultural commodities and crude. The research was also carried out to determine whether the oil's impact on food prices is asymmetric and the period of study was Jan 1990- Oct 2017. ARDL tests confirmed the existence of co-integration relation between Oil Prices and food indices, while NARDL confirmed the asymmetric long run impact of oil prices on food index. Further the asymmetric impact showed that the food prices were impacted only by the rise but not fall in crude prices.

The review of literature which made an attempt to examine the food-crude nexus by taking recent studies, post year 2000 gives two important arguments, first there is no consensus amongst the researchers on whether crude was moving food prices. Many researchers with a large sample period (50 years, 100 years) could not find any food-crude relation even after including the period of food crisis in their sample, second; most of newer studies have found that the relation between crude and food was highly complex and hence models required a nonlinear approach. Such researchers have applied both linear and non linear tests to establish the relation between crude and food crops.

Going forward, we have developed our study which takes forward some of the above mentioned issues and the study would also address some of the other issues like how well does the argument of crudefood nexus fit in a country like India and whether the same nexus continues post food crisis period after the prices of crude and food crops have stabilized in international markets.

Further, accepting the arguments of researchers that the relation between the food crops and crude is not simple but complex, the present study incorporates the non-linear aspects while developing the relationship model. The study also assumes that the time series must have undergone a structural break during the period of the study, and therefore tries to incorporate this aspect as done by some of the recent studies, however in case no break is observed then the results of our model would be similar to a model fitted without a break. 


\section{RESEARCH OBJECTIVES AND METHODS}

The food-oil nexus in India is examined in light of the following research objectives:

(i) To test for possible co-integration between price movement of crude and four agricultural biofuels viz. soy-oil, rapeseed oil, sunflower oil and palm-oil and to determine the error corrective mechanism (if any).

(ii) To test whether there is a cause - effect relation between the crude and biofuels.

(iii) To check for asymmetric relation between movement of crude and biofuels.

(iv) To examine the presence of spill-over (mean or volatility) from crude to biofuels and vice versa.

(v) To identify the structural break during the study period (if any).

The following methods have been employed to achieve these specified research objectives:

(i) Vector Autoregressive Model with Optimal Lag Length as per AIC.

(ii) Toda- Yamamoto Causality.

(iii) Johansen Co-integration and Gregory - Hansen Co-integration procedure.

(iv) GARCH $(1,1)$ Model.

(v) Stationarity tests (using ADF test Statistic) and Normality of Variables (using JB test).

\section{DISTRIBUTION CHARACTERISTICS}

\section{Descriptive Statistics}

The Statistical Description of our variables (CrudeOil, Palm Oil, Sun Flower Oil, Rapeseed Oil and
Soya-Oil) at closing monthly prices for the period Jan 2010- Dec 2019 ( 120 observations for each ) is given in Table 1 below. The table provides information about the Mean, Standard Deviation, Skewness, Kurtosis and other parameters pertaining to the movement of crude and four agricultural crop oils viz. Palm Oil, Sun Flower Oil, Rapeseed Oil and Soya-Oil. A look at the table reveals that standard deviation is lowest for crude \& highest for sunflower oil. All agricultural crop oils have high standard devation which is approximately 5-6 times higher than that of crude reflecting the risk aspect in investing agricultural crop oils. The same observation can be made by comparing the range of their prices which again for crude is one-fifth as compared to to other agricutltural crops. All five distributions, have negative kurtosis (and also negative excess kurtosis) simply reflecting flatter peaks and lighter tails with very little outliers as compared to normal. On the other hand, the skewness of four distributions viz. Crude-Oil, Palm Oil, Sun Flower Oil and Soya-Oil is fairly symmetric while that of rapeseed oil being negatively skewed. The JB Statistics for normality was tested by taking variables at both closing and log closing prices and it was seen that two variables soy-oil and Sun Flower Oil were normally distributed, Crude and Palm Oil were log normal while rapeseed oil distriubtion was neither neither normal nor log normal. Therefore the following decisions were taken in this regard for further analysis (i) Soy - Oil and Sun Flower Oil to be considered at closing prices (ii) Crude and Palm Oil were to be considered at log closing prices and (iii) Rapeseed Oil was considered at closing prices. 
Table 1 : Statistical Description of Variables at closing monthly prices for the period Jan 2010- Dec 2019

\begin{tabular}{|l|c|c|c|c|c|}
\hline Particulars & $\begin{array}{l}\text { Crude Oil } \\
\text { Cl. Prices }\end{array}$ & $\begin{array}{l}\text { Palm Oil Cl. } \\
\text { Prices }\end{array}$ & $\begin{array}{l}\text { Soy Bean Oil } \\
\text { Cl. Prices }\end{array}$ & $\begin{array}{l}\text { Rapeseed Oil } \\
\text { Cl. Prices }\end{array}$ & $\begin{array}{l}\text { Sun Flower } \\
\text { Oil Cl. Prices }\end{array}$ \\
\hline Mean & 4459.0852 & 47381.8613 & 55527.8982 & 57522.8492 & 57338.56 \\
\hline Standard Error & 107.9070 & 552.2345 & 585.2251 & 627.3336 & 642.7415 \\
\hline Standard Deviation & 1182.0625 & 6049.4256 & 6410.8199 & 6872.0956 & 7040.88 \\
\hline Kurtosis & -0.9477 & -0.8426 & -0.0175 & -0.1644 & -0.3382 \\
\hline Skewness & 0.1972 & 0.1444 & -0.2096 & -0.6374 & 0.04152 \\
\hline Range & 4922.83 & 24759.76 & 30407.08 & 29798.15 & 31500.35 \\
\hline Minimum & 2004 & 36419.98 & 39591.5 & 39545.73 & 41117.03 \\
\hline Maximum & 6926.83 & 61179.74 & 69998.58 & 69343.88 & 72617.38 \\
\hline No. of Observations & 120 & 120 & 120 & 120 & 120 \\
\hline $\begin{array}{l}\text { JB Statistics } \\
\frac{n}{6}\left\{\boldsymbol{S}^{2}+\frac{1}{4}(\mathbf{K}-3)^{2}\right\}\end{array}$ & & & & & \\
for Normality & & & & & \\
$\begin{array}{l}\text { (Cl. Prices) } \\
\text { (Ln. Cl. Prices) }\end{array}$ & 6.35 & 7.083 & $0.88^{\#}$ & 8.14 & $0.73^{\#}$ \\
\hline
\end{tabular}

\# Normally Distributed * Log Normally Distributed

\section{Stationarity of Variables}

If for a time series there is no change in characteristics of its statistics (Mean, Variance etc.) overtime, it is called a stationary process. Testing the variables for stationarity is one the foremost test applied before developing any research model and in our study this would act as a deciding factor in developing econometric tools of co-integration and causality.

The test of stationarity used in our research is the popular Augmented Dickey Fuller Unit Root test and the following equation has been developed for this test :-

$\Delta Y_{i, t}=\beta_{1, i}+\left(\beta_{2, i}-1\right) Y_{i,(t-1)}+\sum_{j=1}^{m} \beta_{3, j} \Delta Y_{t-j}+\beta_{4, i} t+u_{i, t} \ldots \ldots \ldots \ldots . . e q .(i)$

\{where ${ }^{\prime} i$ ' $=i^{\text {th }}$ variable; 1 to 5 variables namely Natural Log of Closing Crude Prices, Natural Log of closing Palm Oil prices, Closing Prices of rapeseed oil, Sunflower oil and Soy-oil., $\left(\mathrm{b}_{2, i}-1\right)$ represents the beta coefficient of the Stationarity for variable ' $i$ '. For this beta coefficient, we compute the ' $t$ ' value which is then compared with ADF table value. $\sum_{\mathrm{j}=1}^{\mathrm{m}} \mathrm{b}_{3 \mathrm{j}} \mathrm{D} \mathrm{U}_{\mathrm{t}-\mathrm{j}}$ denotes change in variable $\mathrm{Y}$ in period $t-j$ ( $j$ is the lag) $\mathcal{E}$ this term has been added to stationary equation to take care of serial-correlation. The summation indicates that the term adds up ' $m$ ' lag times till the serial-correlation is removed. The next term is $b_{4, i} t$ and this signifies the trend variable and takes care of possible deterministic trend in the variable ' $i$ ' so that only stochastic trend can be detected by the test and the final term is $u_{i, t}$ which is random error term.\}

The testable hypothesis for Stationarity test of our variable Yi ( eq (I)) would be

$\left(H_{0}\right)$ : Coefficient $\left(b_{2, i}-1\right)=0$ (Variable $Y_{i}$ is not stationary)

$\left(\mathrm{H}_{\mathrm{a}}\right)$ : Coefficient $\left(\mathrm{b}_{2, \mathrm{i}}-1\right)^{1} 0,\left(\mathrm{Y}_{\mathrm{i}}\right.$ is stationary $)$

Acceptance of Null Hypothesis would mean that the variable has a unit root

The results of stationary tests for all our variables are given in Table 2 below. The first column shows the Null Hypothesis, second column shows the computed ' $t$ ' values for the variable at Closing Prices (or level) while third column shows computed ' $t$ ' values at $1^{\text {st }}$ difference (or integrated at order 1 ). The results clearly reveal that all our variables are I(1) Stationary and this result would be useful in development of subsequent models. 
Table 2: Test of Stationary of Variables : Unit Root ADF

\begin{tabular}{|c|c|c|c|}
\hline Null Hypothesis & $\begin{array}{c}\text { Computed ADF ' } t \text { ' } \\
\text { values at level (' } p \text { ' } \\
\text { values In } \\
\text { parenthesis) }\end{array}$ & $\begin{array}{l}\text { Computed ADF 't' } \\
\text { values at } 1^{\text {st }} \text { diff. } \\
\text { (' } p \text { ' values in } \\
\text { parenthesis) }\end{array}$ & $\begin{array}{c}\text { Test } \\
\text { Result }\end{array}$ \\
\hline $\begin{array}{l}\text { Crude Oil has a unit } \\
\text { root }\end{array}$ & $\begin{array}{c}-2.281304 \\
(0.4404)\end{array}$ & $\begin{array}{c}-7.984564 \\
(0.0000)\end{array}$ & $\begin{array}{l}\text { Null Hypothesis } \\
\text { rejected at } 1^{\text {st }} \text { difference }\end{array}$ \\
\hline $\begin{array}{l}\text { Palm Oil has a unit } \\
\text { root }\end{array}$ & $\begin{array}{c}-3.311528 \\
(0.0694)\end{array}$ & $\begin{array}{l}-8.486596 \\
(0.0000)\end{array}$ & $\begin{array}{l}\text { Null Hypothesis } \\
\text { rejected at } 1^{\text {st }} \text { difference }\end{array}$ \\
\hline $\begin{array}{l}\text { Rapeseed Oil has a } \\
\text { unit root }\end{array}$ & $\begin{array}{c}-2.323664 \\
(0.4177)\end{array}$ & $\begin{array}{c}-8.222864 \\
(0.0000)\end{array}$ & $\begin{array}{l}\text { Null Hypothesis } \\
\text { rejected at } 1^{\text {st }} \text { difference }\end{array}$ \\
\hline $\begin{array}{l}\text { Sunflower Oil has a } \\
\text { unit root }\end{array}$ & $\begin{array}{c}-2.764241 \\
(0.2135)\end{array}$ & $\begin{array}{c}-7.466252 \\
(0.0000)\end{array}$ & $\begin{array}{l}\text { Null Hypothesis } \\
\text { rejected at } 1^{\text {st }} \text { difference }\end{array}$ \\
\hline $\begin{array}{l}\text { Soya Oil has a unit } \\
\text { root }\end{array}$ & $\begin{array}{c}-2.480715 \\
(0.3371)\end{array}$ & $\begin{array}{l}-8.695883 \\
(0.0000)\end{array}$ & $\begin{array}{l}\text { Null Hypothesis } \\
\text { rejected at } 1^{\text {st }} \text { difference }\end{array}$ \\
\hline
\end{tabular}

Note: Critical ' $t$ ' value at $5 \%$ level for ADF (with trend and intercept) is -3.448

\section{RESEARCH METHODOLOGY AND TESTING OF HYPOTHESIS}

\section{Developing a Co-integration Model}

To examine the long term relationship between variables, Johansen (1998) Co-integration Model has been used in our study.

\subsection{Johansen Co-integration Model}

The model is developed using a simple VAR Model which is shown as under:-

$Y_{i t}=\mu+\pi_{i, 1} Y_{i,(t-1)}+\pi_{i, 2} Y_{i,(t-2)}+\ldots \ldots . .+\pi_{i, k} Y_{i,(t-k)}+e_{i, t} \ldots \ldots \ldots \ldots \ldots(i i)$

$m=$ constant $k=$ no. of lags, et the error term and $p 1$, $p 2, p 3 \ldots \ldots \ldots$ are the coefficients of VAR terms. ' $t$ ' is the time period and ' $i$ ' is $i^{\text {th }}$ variable

The above model (ii) may be written as

$\Delta Y_{i t}=\mu+\left(\pi_{i, 1}-1\right)\left(Y_{i(t-1)}\right)+\pi_{i, 2} \Delta Y_{i(t-1)}+\pi_{i, 3} \Delta Y_{i(t-2)}+\ldots .+\pi_{i, k} \Delta Y_{i(t-(k-1))} \ldots . . .(i i i)$

Now Let $q_{i}=\left(p_{i, 1}-1\right)$ represent a matrix of coefficients signifying long term relation among the variables

$$
\text { i.e. } q_{\mathrm{i}}=\left(\begin{array}{cccc}
\boldsymbol{\beta}_{11 i} & \boldsymbol{\beta}_{12 i} & \cdots & \boldsymbol{\beta}_{1 m i} \\
\boldsymbol{\beta}_{21 i} & \cdots & & \vdots \\
\boldsymbol{\beta}_{m 1 i} & \cdots & & \boldsymbol{\beta}_{m m i}
\end{array}\right)
$$

is the fundamental matrix of the co-integration.

However our interest lies in the rank of the matrix $q$ as all the vectors need not be co-integrated. If there is no co-integration, Matrix $q$ has a rank ' 0 ', if cointegration is detected we proceed towards computation of characteristic roots and eigen values.

\subsection{Gregory Hansen Co-integration Model (1996)}

Under the present research, we test for cointegration using another model viz. the Gregory Hansen Co-integration Model. The main reason behind using this model is that the previous model namely Johansen Model does not consider a structural break in time series analysis and it is most likely to conclude that there is no co-integration between variables even though there might be cointegration. In the presence of a break in time series, there is high probability that the co-integrating relationship undergoes a change at the break point. Therefore in order to improvise our results, we use Gregory - Hansen Co-integration Model which has three types i.e. level shift, level shift with trend and 
regime shift (or shift in both slope and intercept). The following are the equations for these models:

Level Shift only: $Y_{t}=b_{1}+b^{*}{ }_{1} D_{1, t}+b_{2} X_{t}+u_{1 t}$

Level Shift with trend: $Y_{t}=b_{1}+b^{*}{ }_{1} D_{1, t}+b_{2} X_{t}+b_{3} t+u_{2 t}$

Regime Shift: $Y_{t}=b_{1}+b^{*} D_{1}+b_{2} X_{t}+b^{*}{ }_{2} D_{2} X t+u_{3 t}$

In case of level shift model (given in equation (iv)), there is a change in intercept while keeping the slope coefficient as constant. $\mathrm{D}_{1}$ is the dummy variable for shift in intercept. Thus intercept before the shift shall be $b_{1}$ while intercept after the shift shall be $b_{1}+b^{*}$. Dummy $D_{1}$ is defined as equal to 1 , if $\mathrm{t}>$ Break Date and 0 otherwise (i.e. if " $t$ " is at break or before breakpoint)

In case of level shift model with a trend (given in equation (v)), the model is similar to first one however trend variable has been added so as to detrend the same. This simply means that in case a trend exists then by including this term we can focus on level shift and the term trend variable takes care of any shift which might have occurred due to trend.

The third model is a regime shift (i.e. shifting at both intercept and slope) (given in equation (vi)). This model includes two dummies $D_{1}$ for a shift in intercept and $\mathrm{D}_{2}$ for shift in slope. Both being defined as $=1$, if $\mathrm{t}>$ Break Date and 0 otherwise.

Null Hypothesis: No Co-integration at break point.

Alternate Hypothesis: Co-integration exists at a single breakpoint.

The test criteria values are directly taken from ADF $(\mathrm{t})$ and Philip test statistics as $\mathrm{Z}_{\mathrm{t}}(\mathrm{t})$ and $\mathrm{Z}_{\mathrm{a}}(\mathrm{t})$

Decision Criteria: $\mid$ ADF (t) $|,| Z_{t}(t) \mid$ and $\left|Z_{a}(t)\right|>$ critical, reject the null hypothesis

If the null is rejected, it simply means that linear combination of our variables exhibit long run stable characteristics (co-integration).

\section{Developing a causality model}

Causality is a concept of establishing cause effect relation between the variables and also specifies the direction of its relationship. In order to develop a correct causality model, we must know the integration level (stationary level) of all the variables and since our results reveal that all the variables are I(1) integrated, we cannot use the traditional granger causality to test our variables as the variables no longer shall be following standard normal distribution and therefore the results obtained will not be robust. Hence we use an alternate causality test which has been given by Toda, H. Y., \& Yamamoto, T. (1995) and is simply a modified Wald test (MWALD) based upon augmented VAR.

Consider two variables $Y_{1}$ and $Y_{2}$ and we are test for causality ; $Y_{2} \rightarrow Y_{1}$, we develop the following two equations : restricted model; eq. (vii) and unrestricted model; eq. (viii). Optimal length of each of the variables has been determined using AIC, Let this be ' $h$ ' for Dependent variable $Y_{1} \&$ ' $k$ ' for Independent variable $\mathrm{Y}_{2}$.

\subsection{Restricted Model :}

$$
Y_{1 t}=\lambda_{0}+\sum_{j=1}^{I m a x} \alpha_{j} Y_{2, t-1\}}+\sum_{i=1}^{h+\operatorname{Imax}} \beta_{j} Y_{1, t-1,}+u_{t \ldots \ldots \ldots \ldots . . . . .(v i i)}
$$

The above restricted model (equation vii) has a constant I. and lags of both variables; independent $Y_{2}$ and dependent $Y_{1}$. These lags sum up to 'Imax' for independent variable $Y_{2}$ and ' $h+$ Imax' for dependent variable $Y_{1}$. The maximum no. of lags for dependent variable $Y_{1}$ is given by ' $h+$ Imax' ; ' $h$ ' is already known is the optimal no. of lags as per AIC and 'Imax' is the maximum order of integration of two variables while the no. of lags of the independent variable $Y_{2}$ is given by 'Imax' only. We have $u_{t}$ as the error term.

\subsection{Un-Restricted Model}

$$
Y_{1 t}=\lambda_{0}+\sum_{j=1}^{k+I \max } \alpha_{j} Y_{2, t-1\}}+\sum_{i=1}^{h+I \max } \beta_{j} Y_{1, t-1,}+v_{t} \ldots \ldots \ldots \text { (viii) }
$$

Under Un-restricted Model (equation viii) we have augmented lags i.e. maximum number of lags of dependent variable $Y_{1}$ given by ' $h+$ Imax' (same as restricted model) while the lags of $Y_{2}$ shall be ' $k+$ Imax'. 
' $k$ ' is optimal lags as per AIC for Independent variable $Y_{2}$ and 'Imax' is the maximum order of integration of two variables. We have $v_{t}$ as the error term.

Null Hypothesis: Lagged values of $Y_{2}$ do not influence $Y_{1}$ i.e. $a_{1}=a_{2}=a_{3} \ldots .=0$

Alt Hypothesis: Lagged values of $Y_{2}$ influence $Y_{1}$ i.e. $a_{1}=a_{2}=a_{3} \ldots{ }^{1} \quad 0$

Decision Criteria: We compute Modified ' $\mathrm{F}$ ' Wald and if $\mathrm{F}_{\text {M. Wald }}>\mathrm{F}_{\text {Table }}$ at $5 \%$, reject Null Hypothesis

$$
\operatorname{Mod} F_{{ }^{\prime} \text { Wald }^{\prime}}=\frac{\left(\text { RSS }_{\text {rest }}-\text { RSS }_{\text {unres }}\right) / \boldsymbol{k}}{\text { RSS }_{\text {unres }} /(\boldsymbol{n}-\boldsymbol{k})}
$$

(Where RSS : Residual Sum of the Squares, ' $k$ ' is the degree of freedom of the numerator which is equal to number of parameters to be estimated, ' $n$ ' being number of observations)

\section{Developing a spill-over model}

Under this we develop our contemporaneous spillover models; to ascertain whether or not there is spill-over of mean and/or volatility from one variable to another. We start with usual GARCH (1, 1) Model and incorporate the standardized residuals and standardized squared residuals of other variables. For each of the five variables namely crude oil, soy-oil, rapeseed oil, sunflower oil and palm-oil we develop a GARCH $(1,1)$ model showing conditional mean and variance equations as under :

\section{Conditional Mean and Variance Equations}

Consider equation (ix) which is the conditional mean equation for $\mathrm{i}^{\text {th }}$ variable. This equation (ix) has been developed as a simple AR(1) model with other terms as contemporary residuals of similar equations of other variables. Also equation (xii) which is the conditional variance equation for $\mathrm{i}^{\text {th }}$ variable has been developed as a GARCH $(1,1)$ model which has a constant term $a_{1}, A R C H$ term $v_{i t-1}^{2}$ and a GARCH term $h_{i, t-1}$. The equation (xii) also includes other terms as contemporary residuals squares of similar equations of other variables.

$$
\begin{aligned}
& Y_{i, t}=\beta_{1}+\beta_{2} Y_{i, t-1}+\beta_{3, j} \sum_{j=1}^{4} u_{j, t}+v_{i, t} \ldots \ldots(i x) \\
& h_{i, t}=\alpha_{1}+\alpha_{2} \mathrm{~V}_{\mathrm{i} t-1}^{2}+\alpha_{3} h_{i, t-1}+\alpha_{4, \mathrm{j}} \sum_{j=1}^{4} u_{j, t}^{2} \ldots \ldots(x)
\end{aligned}
$$

$\left\{i^{\text {th }}\right.$ variable, ' $\mathrm{i}$ ' $=1$ to 5 or Crude-Oil, Palm Oil, Sun Flower Oil, Rapeseed Oil and Soya-Oil, ' $\mathrm{j}$ ' $=1$ to 4 , $\mathrm{v}_{\mathrm{i}, \mathrm{t}}{ }^{\prime}$ is the residual term of eq.(ix), $\mathrm{u}_{\mathrm{j}, \mathrm{t}}$ represents standardized residuals of equations of other variables, while $\mathrm{u}_{\mathrm{j}, \mathrm{t}}^{2}$ represents standardized residuals squares of equations of other variables $\}$

\section{EMPIRICAL RESULTS}

The empirical results of the study are given in tabular format in appendices. Appendix I (a) \& (b) gives the results of the Johansen co-integration test in two tables; table $\mathrm{I}(\mathrm{a})$ as Unrestricted Cointegration Rank Test (Trace) and table $\mathrm{I}(\mathrm{b})$ as Unrestricted Co-integration Rank Test (Max Eigen value). The results reveal that whereas table I(a) shows there is one co-integrating relation, table $\mathrm{I}(\mathrm{b})$ shows there is None. Ideally co-integration shall be proved in our results if the results obtained from table I(a) Unrestricted Co-integration Rank Test (Trace) \& table $\mathrm{I}(\mathrm{b})$ (Max Eigen value) match. However since the results do not match and are contradictory i.e. Trace Statistics reveal there is one co-integration pair, while the Max Eigen shows no pair of co-integration, we must conduct another cointegration test and the test we selected was Gregory Hansen Co-integration (GH) 1996 test as it was capable of detecting co-integration in the presence of a break.

Under Gregory - Hansen Co-integration Model we have applied all the three types of models i.e. level shift, shift in level with trend and regime shift; results of the same are given in Appendix II. Since the model checks for co-integration after incorporating single structural break, the three structural dates are also shown along with the results. Three computations made under the GH test are $\operatorname{ADF}(t), Z a(t)$ and $Z t(t)$ are these are shown in Appendix II. The critical values at $5 \%$ for $\operatorname{ADF}(t), Z a$ $(\mathrm{t})$ and $\mathrm{Zt}(\mathrm{t})$ are given as a note below the table. The 
results of Gregory - Hansen Co-integration tests reveal that no co-integration exists when we compare the absolute values of computed parameters $\mathrm{ADF}(\mathrm{t}), \mathrm{Za}(\mathrm{t})$ and $\mathrm{Zt}(\mathrm{t})$ with critical values at $5 \%$ and therefore conclude that no cointegration exists as all computed parameters are lower in their absolute values.

The next appendix (Appendix III) gives the results of the Causality tests and since the variables are I(1) integrated we have applied Toda \& Yamamoto (1995) Causality test where we are testing unidirectional causality moving from crude to agro based bio-fuels. The results do not support any causality movement as the Null Hypothesis of No Causality is accepted in all the cases. The detailed VAR Model for the same based upon AIC optimal lag criteria is shown separately as Appendix IV.

Appendix V shows the Contemporaneous Spill-Over Results of Mean and Volatility amongst all the Variables. The model employed is the popular GARCH $(1,1)$ Model. Mean and Variability Spill-over has been tested by incorporating standardized residuals and squared standardized residuals of other variables in the mean and variance equations respectively. The spill-over results are given for Crude Oil, Palm Oil, Rapeseed Oil, Sun Flower Oil and Soy Oil and these are given from Appendix (Va) to $(\mathrm{Ve})$ respectively. These results reveal that no mean and variance spill-over exists from other variables to crude, on the other hand crude has been associated with mean spill-over to rapeseed oil and variance spill-over to rapeseed oil and sunflower oil. Amongst the spill-over within the energy crops, mean spill-over is quite widespread and is seen from soy-oil and sunflower oil to palm oil, soy-oil to rapeseed oil, mean spill-over is also seen from sunflower, palm, rapeseed to soy oil \& soy-oil to sunflower oil. Then variance spill-over within energy crops is however limited and is seen only in the case of sun flower to soy oil.

\section{CONCLUDING REMARKS AND STUDY IMPLICATIONS}

The present study made an attempt to examine whether or not the impact of crude oil on energy crops still holds \& continues to impact the bio-fuel prices especially for a country like India. The study covered a period of ten years ; Jan 2010 - Dec 2019, post food crisis of 2006 including three years of stabilization of food prices. The bio-fuels considered in the study were soy-oil, rapeseed oil, sunflower oil and palm-oil. The econometric tools used to examine the relationship included Johansen Co-integration, Gregory Hansen Co-integration with structural breaks, Toda and Yamamoto Causality and GARCH $(1,1)$ Model. The analysis provided no evidence regarding the impact of crude oil on biofuel prices. There was no long run inter-linkages between crude oil and energy crops except a limited volatility spillover which was flowing from crude to two energy crops. In a nutshell, energy-food nexus was a temporary phenomenon that existed during food crisis (2006) only and crude prices were no longer a guiding force to determine the price of biofuels.

There are few important implications from the results of our study, first, an end to the linkages between food crops and crude should come as a big relief for the government as shift towards fuel crops by farmers was gaining speed and all this was coming at the cost of decreased output of other food crops thereby impacting the entire agriculture sector. Second, since the crude prices are determined at an international level and with most of the factors which result in rise or fall in their prices beyond our control, de-linking of food crops with crude prices would surely result in having greater local control over the prices of these crops which is very important for a country like ours, where agriculture is still the backbone of the economy. Third, when the prices of commodities are determined independently on the basis of local demand and supply, it also results in reduction in hoarding of commodities which was quite common with these crops as the hoarders used to play for higher bio-fuel prices in 
view of any major international development.

\section{REFERENCES}

Abdul-Rahim, A. S., and Zariyawati, M. A. (2011) Causal effects of world crude oil prices on the prices of rice and soybean oil: An ardl approach. Pertanika Journal Social Science and Humanities, 19(1), pp.123-130.

Bakhat, M., and Würzburg, K. (2013) Co-integration of oil and commodity prices: a comprehensive approach. Economics for Energy Working Paper WP FA05, pp. 1-24.

Cabrera, B. L., and Schulz, F. (2016) Volatility linkages between energy and agricultural commodity prices. Energy Economics, 54, pp. 190-203.

Fowowe, B. (2016) Do oil prices drive agricultural commodity prices? Evidence from South Africa. Energy, 104, pp.149-157.

Gregory, A. W., and Hansen, B. E. (1996) Practitioners' corner: tests for cointegration in models with regime and trend shifts. Oxford bulletin of Economics and Statistics, 58(3), pp.555-560.

Hansen, B. E., and Queen's University (Kingston, Ont.) Institute for Economic Research. (1992) Residual-based tests for cointegration in models with regime shifts. Kingston, Ont.: Institute for Economic Research, Queen's University.

Johansen S (1988) Statistical Analysis of CoIntegration Vectors, Journal of Economic Dynamics and Control, Vol. 12, Nos. 2 and 3, pp. 231-254.

Johansen S and Juselius K (1990) Maximum Likelihood Estimation and Inference on Cointegration - With Applications to the Demand for Money, Oxford Bulletin of Economics and Statistics, Vol. 52, No. 2, pp. 169210.

Kang, S. H., McIver, R., and Yoon, S. M. (2017) Dynamic spill-over effects among crude oil, precious metal, and agricultural commodity futures markets. Energy Economics, 62, pp.19-32.

Kaushik, N. (2018) Do global oil price shocks affect
Indian metal market? Energy and Environment, 29(6), pp.891-904.

Mitchel, D. (2008) A note on rising food prices. The World Bank.

Natanelov, V., Alam, M. J., McKenzie, A. M., and Van Huylenbroeck, G. (2011) Is there comovement of agricultural commodities futures prices and crude oil?, Energy Policy, 39(9), pp.4971-4984.

Nazlioglu, S., and Soytas, U. (2011) World oil prices and agricultural commodity prices: Evidence from an emerging market. Energy Economics, 33(3), pp.488-496.

Nazlioglu, S., Erdem, C., and Soytas, U. (2013) Volatility spillover between oil and agricultural commodity markets. Energy Economics, 36, pp. 658-665.

Rafiq, S., and Bloch, H. (2016) Explaining commodity prices through asymmetric oil shocks: Evidence from nonlinear models. Resources Policy, 50, pp.34-48.

Zafeiriou, E., Arabatzis, G., Karanikola, P., Tampakis, S., and Tsiantikoudis, S. (2018) Agricultural commodities and crude oil prices: an empirical investigation of their relationship. Sustainability, 10(4), pp.1-11.

Toda, H. Y., and Yamamoto, T. (1995). Statistical inference in vector autoregressions with possibly integrated processes. Journal of econometrics, 66(1-2), pp. 225-250.

Yang, J., Qiu, H., Huang, J., and Rozelle, S. (2008) Fighting global food price rises in the developing world: the response of China and its effect on domestic and world markets. Agricultural Economics, 39, pp.453-464.

Zmami, M., and Ben-Salha, O. (2019) Does oil price drive world food prices? Evidence from linear and nonlinear ARDL modeling. Economies, 7(1), pp.1-18. 
Appendices

Appendix I: Result of Johansen Co-integration between CRUDE, PALM OIL, SOY OIL, RS OIL and SF OIL

(a) Unrestricted Co-integration Rank Test (Trace)

\begin{tabular}{|c|c|c|c|}
\hline $\begin{array}{c}\text { Hypothesized } \\
\text { No. of CE(s) }\end{array}$ & $\begin{array}{c}\text { Trace } \\
\text { Statistic }\end{array}$ & $\begin{array}{c}\mathbf{0 . 0 5} \\
\text { Critical Value }\end{array}$ & Prob. \\
\hline None & 74.75859 & 69.81889 & $0.0191^{*}$ \\
\hline At Most 1 & 46.77807 & 47.85613 & 0.0629 \\
\hline At Most 2 & 21.36250 & 29.79707 & 0.3354 \\
\hline At Most 3 & 7.613190 & 15.49471 & 0.5076 \\
\hline At Most 4 & 2.029273 & 3.841466 & 0.1543 \\
\hline & & & \\
\hline
\end{tabular}

(b) Unrestricted Co-integration Rank Test (Max Eigen value)

\begin{tabular}{|c|c|c|c|}
\hline $\begin{array}{c}\text { Hypothesized } \\
\text { No. of CE(s) }\end{array}$ & Max Eigen Statistic & $\begin{array}{c}\mathbf{0 . 0 5} \\
\text { Critical Value }\end{array}$ & Prob. \\
\hline None & 27.98052 & 33.87687 & $0.2144^{*}$ \\
\hline At Most 1 & 25.41557 & 27.58434 & 0.0924 \\
\hline At Most 2 & 13.74931 & 21.13162 & 0.3860 \\
\hline At Most 3 & 5.583917 & 14.26460 & 0.6670 \\
\hline At Most 4 & 2.029273 & 3.841466 & 0.1543 \\
\hline
\end{tabular}

Appendix II: Result of Gregory Hansen Co-integration between CRUDE, group of (PALM OIL, SOY OIL, RS OIL and SF OIL)

\begin{tabular}{|c|c|c|c|c|c|}
\hline Model & $\begin{array}{c}\text { Computed } \\
\text { ADF(t) }\end{array}$ & $\begin{array}{c}\text { Computed } \\
\mathbf{Z}_{\mathbf{t}}(\mathrm{t})\end{array}$ & $\begin{array}{r}\text { Computed } \\
\mathbf{Z a}(\mathrm{t})\end{array}$ & Break Point & Result \\
\hline Level Shift & -4.96 & -4.25 & -33.31 & Mar,2016 & $\begin{array}{c}\text { No Co- } \\
\text { integration }\end{array}$ \\
\hline $\begin{array}{c}\text { Level Shift } \\
\text { with trend }\end{array}$ & -5.92 & -4.71 & -39.71 & Feb, 2015 & $\begin{array}{c}\text { No Co- } \\
\text { integration }\end{array}$ \\
\hline $\begin{array}{c}\text { Regime } \\
\text { Shift }\end{array}$ & -5.34 & -4.26 & -33.86 & Jan,2016 & $\begin{array}{c}\text { No Co- } \\
\text { integration }\end{array}$ \\
\hline
\end{tabular}

Note: Critical Value for both ADF ('t ') and $\mathrm{Z}_{t}(\mathrm{t})$ statistics at $5 \%$ is given as -6.84 . Also

Critical Value for $Z_{a}(\mathrm{t})$ statistics at $5 \%$ is -88.47

\section{APPENDIX IIITodaand Yamamoto (1995)CAUSALITY Test Results}

\begin{tabular}{|l|c|l|l|l|}
\hline Type ofRelation tested & Obs. & $\begin{array}{l}\text { Observed } \\
\text { Chi-Sq Value }\end{array}$ & $\begin{array}{l}\text { Probability ' } \\
\text { value }\end{array}$ & Result \\
\hline CRUDE $\rightarrow$ PALM OIL & 120 & 2.332588 & 0.3115 & No Causality \\
\hline CRUDE $\rightarrow$ RS-OIL & 120 & 1.197233 & 0.5496 & No Causality \\
\hline CRUDE $\rightarrow$ SF-OIL & 20 & 0.694529 & 0.7066 & No Causality \\
\hline CRUDE $\rightarrow$ SOY- OIL & 20 & 3.193097 & 0.2026 & No Causality \\
\hline
\end{tabular}


APPENDIX IV: VAR ESTIMATION RESULTS (Augmented for Toda, H. Y., and Yamamoto, T. (1995) CAUSALITY)

\begin{tabular}{|c|c|c|c|c|c|}
\hline \multirow[t]{2}{*}{ IND. VARIABLE } & \multicolumn{5}{|c|}{ DEPENDENT VARIABLE } \\
\hline & CRUDE & PALM OIL & RS OIL & SF OIL & SOY OIL \\
\hline \multirow[t]{2}{*}{ CRUDE(-1) } & 1.212118 & 0.021516 & 0.058533 & 0.042293 & 0.077585 \\
\hline & [11.2677] & [ 0.27284] & [ 1.08134$]$ & {$[0.72655]$} & {$[1.48590]$} \\
\hline \multirow[t]{2}{*}{ CRUDE(-2) } & -0.352895 & -0.135029 & -0.059557 & -0.071173 & -0.138210 \\
\hline & {$[-2.20644]$} & {$[-1.15169]$} & {$[-0.74004]$} & {$[-0.82238]$} & {$[-1.78036]$} \\
\hline \multirow[t]{2}{*}{ PALM OIL(-1) } & 0.428814 & 1.133581 & -0.054904 & -0.101895 & 0.034922 \\
\hline & [ 2.32267] & [ 8.37591] & {$[-0.59101]$} & {$[-1.01995]$} & {$[0.38970]$} \\
\hline \multirow[t]{2}{*}{ PALM OIL(-2) } & -0.657969 & -0.497579 & -0.124820 & -0.129694 & -0.217698 \\
\hline & {$[-2.32714]$} & {$[-2.40070]$} & {$[-0.87735]$} & {$[-0.84770]$} & {$[-1.58632]$} \\
\hline \multirow[t]{2}{*}{ RS OIL $(-1)$} & -0.635186 & -0.217130 & 1.015083 & 0.194187 & 0.077347 \\
\hline & {$[-2.30049]$} & {$[-1.07275]$} & {$[7.30621]$} & [1.29971] & {$[0.57715]$} \\
\hline \multirow[t]{2}{*}{ RS OIL ( -2) } & 0.680647 & 0.267411 & -0.261390 & -0.260650 & 0.134903 \\
\hline & {$[1.73346]$} & [ 0.92904] & {$[-1.32298]$} & {$[-1.22675]$} & {$[0.70784]$} \\
\hline \multirow[t]{2}{*}{ SF OIL(-1) } & -0.092264 & 0.009136 & 0.140399 & 1.073124 & -0.019818 \\
\hline & {$[-0.39813]$} & [0.05378] & [1.20400] & [ 8.55751] & {$[-0.17619]$} \\
\hline \multirow[t]{2}{*}{ SF OIL $(-2)$} & -0.028750 & 0.006799 & -0.036471 & -0.222380 & 0.211864 \\
\hline & {$[-0.08716]$} & [ 0.02812] & {$[-0.21973]$} & [-1.24589] & [ 1.32329] \\
\hline \multirow[t]{2}{*}{ SOY OIL (-1) } & 0.229260 & 0.118159 & 0.118824 & 0.091215 & 0.981421 \\
\hline & [ 0.65929] & [0.46352] & [ 0.67908] & [0.48475] & [5.81465] \\
\hline \multirow[t]{2}{*}{ SOY OIL (-2) } & 0.249673 & 0.291641 & 0.184019 & 0.192291 & -0.168848 \\
\hline & {$[0.55224]$} & [0.87996] & [ 0.80889] & [0.78599] & {$[-0.76943]$} \\
\hline \multirow[t]{2}{*}{ CONSTANT } & -0.767419 & 0.830457 & 0.983751 & 1.094022 & 0.696185 \\
\hline & [-1.05415] & [1.55613] & [ 2.68550] & [ 2.77717] & [ 1.97022$]$ \\
\hline \multirow[t]{2}{*}{ CRUDE(-3) } & 0.037661 & 0.101305 & 0.002452 & 0.035129 & 0.058850 \\
\hline & [ 0.37582] & [1.37903] & [ 0.04863] & [ 0.64782] & [ 1.20990] \\
\hline \multirow[t]{2}{*}{ PALM OIL(-3) } & 0.161176 & 0.242362 & 0.147328 & 0.198285 & 0.215457 \\
\hline & [ 0.81737] & [1.67664] & [1.48481] & [1.85829] & [2.25111] \\
\hline \multirow[t]{2}{*}{ RS OIL( $(-3)$} & -0.253127 & 0.010954 & 0.162416 & 0.006631 & -0.123957 \\
\hline & {$[-0.83713]$} & [ 0.04942] & [1.06747] & [ 0.04052] & {$[-0.84459]$} \\
\hline \multirow[t]{2}{*}{ SF OIL $(-3)$} & -0.002989 & 0.029142 & -0.070165 & 0.105379 & -0.153370 \\
\hline & {$[-0.01317]$} & [ 0.17519] & {$[-0.61448]$} & [ 0.85817] & {$[-1.39244]$} \\
\hline \multirow[t]{2}{*}{ SOY OIL( $(-3)$} & 0.070191 & -0.463025 & -0.311509 & -0.251521 & -0.034336 \\
\hline & [ 0.19839] & {$[-1.78521]$} & [-1.74972] & {$[-1.31374]$} & {$[-0.19994]$} \\
\hline \multicolumn{6}{|l|}{ Model Accuracy } \\
\hline $\mathrm{R}^{2}$ & 0.943295 & 0.848869 & 0.919459 & 0.910274 & 0.918890 \\
\hline F-Statistic & 112.0097 & 37.81970 & 76.86836 & 68.31029 & 76.28171 \\
\hline AIC & -2.340348 & -2.961398 & -3.713938 & -3.568581 & -3.786007 \\
\hline
\end{tabular}


APPENDIX V: GARCH (1,1) Contemporaneous Spill-Over Results of Mean and Volatility amongst the Variables

Appendix V (a) Spill-over from other variables to Crude Oil

\begin{tabular}{|c|c|c|c|c|}
\hline \multicolumn{5}{|c|}{ DEPENDENT VARIABLE : CRUDE } \\
\hline MEANEQUATION & $\begin{array}{c}\text { Beta } \\
\text { Coefficient }\end{array}$ & 'p' value & $\begin{array}{c}\text { Spill-over } \\
\text { (Yes/No) }\end{array}$ & RESULT \\
\hline CRUDE(-1) & 0.999808 & 0.0000 & - & \\
\hline Std Residuals : Palm Oil & 0.017454 & 0.2290 & NO & Neither \\
\hline Std Residuals : RS Oil* & 0.011058 & 0.5134 & NO & Mean \\
\hline Std Residuals : SOYOil** & 0.002958 & 0.8754 & NO & Volatility \\
\hline Std Residuals : SF Oil*** & -0.009948 & 0.5566 & NO & Spill - \\
\hline VARIANCE_EQATION & & & NO & NO \\
\hline $\begin{array}{c}\text { Std Residuals SQR : Palm } \\
\text { Oil }\end{array}$ & -0.000329 & 0.6870 & NO & \\
\hline $\begin{array}{c}\text { Std Residuals SQR : RS } \\
\text { Oil }\end{array}$ & -0.000278 & 0.6427 & NO & \\
\hline $\begin{array}{c}\text { Std Residuals SQR : SOY } \\
\text { Oil }\end{array}$ & -0.000288 & 0.7816 & & \\
\hline Std Residuals SQR : SF & -0.000176 & 0.7013 & & \\
Oil & & & & \\
\hline
\end{tabular}

* Rapeseed Oil ** Soy-Bean Oil *** Sunflower Oil

Note: (1) Used GARCH $(1,1)$ Model with mean equation as simple AR(1)

\section{Appendix V (b) Spill-over from other variables to Palm Oil}

\begin{tabular}{|c|c|c|c|c|}
\hline \multicolumn{5}{|c|}{ DEPENDENT VARIABLE : PALM OIL } \\
\hline MEAN EQUATION & $\begin{array}{c}\text { Beta } \\
\text { Coefficient }\end{array}$ & 'p' value & $\begin{array}{c}\text { Spill-over } \\
\text { (Yes/No) }\end{array}$ & RESULT \\
\hline PALM OIL( $(-1)$ & 1.000268 & 0.0000 & - & \\
\hline Std Residuals : Crude & 0.006412 & 0.1859 & $\mathrm{NO}$ & Only \\
\hline Std Residuals : RS Oil* & 0.003906 & 0.4958 & $\mathrm{NO}$ & Mean \\
\hline Std Residuals : SOY Oil ${ }^{* *}$ & 0.026422 & 0.0000 & $\mathrm{YES}^{\wedge}$ & Spill - \\
\hline Std Residuals : SF Oil ${ }^{* * *}$ & 0.008995 & 0.0176 & $\mathrm{YES}^{\wedge}$ & over \\
\hline & & & & w.r.t \\
\hline VARIANCE EQUATION & & & & Soy Oil \& \\
\hline Std Residuals SQR : Crude & 0.000167 & 0.4763 & $\mathrm{NO}$ & Sunflower \\
\hline Std Residuals SQR : RS Oil & 2.06E-05 & 0.9271 & $\mathrm{NO}$ & Oil \\
\hline Std Residuals SQR : SOY Oil & $-7.19 \mathrm{E}-05$ & 0.7663 & $\mathrm{NO}$ & \\
\hline Std Residuals SQR : SF Oil & $-5.35 \mathrm{E}-05$ & 0.7761 & $\mathrm{NO}$ & \\
\hline
\end{tabular}

$\wedge$ at $5 \%$ level of significance, @ at $10 \%$ level of significance 
Appendix V (c) Spill-over from other variables to Rapeseed Oil

\begin{tabular}{|c|c|c|c|c|}
\hline \multicolumn{2}{|c|}{ DEPENDENT VARIABLE : RS OIL(RAPESEED OIL) } \\
\hline MEAN EQUATION & $\begin{array}{c}\text { Beta } \\
\text { Coefficient }\end{array}$ & $\begin{array}{c}\text { 'p' } \\
\text { value }\end{array}$ & $\begin{array}{c}\text { Spill-over } \\
\text { (Yes/No) }\end{array}$ & RESULT \\
\hline RS OIL( -1) & 1.000294 & 0.0000 & - & Mean \\
\hline Std Residuals : Crude & 0.006982 & 0.0428 & YES^ $^{\wedge}$ & Spill - \\
\hline Std Residuals : PALM Oil & -0.000596 & 0.8917 & NO & over \\
\hline Std Residuals : SOY Oil & 0.023006 & 0.0000 & YES^ & w.r.t \\
\hline Std Residuals : SF Oil & 0.004707 & 0.3625 & NO & Soy Oil and \\
\hline VARIANCE EQUATION & & & & Crude \\
\hline Std Residuals SQR : Crude & $-5.90 \mathrm{E}-05$ & 0.0520 & YES@ & Variance \\
\hline Std Residuals SQR : PALM Oil & $-1.32 \mathrm{E}-05$ & 0.8258 & & Over \\
\hline Std Residuals SQR : SOY Oil & $-3.92 \mathrm{E}-05$ & 0.5977 & & w.r.t \\
\hline Std Residuals SQR : SF Oil & $-2.86 \mathrm{E}-05$ & 0.6145 & & Crude \\
\hline
\end{tabular}

$\wedge$ at $5 \%$ level of significance, @ at $10 \%$ level of significance

Appendix V (d) Spill-over from other variables to Soy- Oil

\begin{tabular}{|c|c|c|c|c|}
\hline \multicolumn{5}{|c|}{ DEPENDENT VARIABLE : SOY OIL } \\
\hline MEAN EQUATION & $\begin{array}{c}\text { Beta } \\
\text { Coefficient }\end{array}$ & 'p $^{\prime}$ value & $\begin{array}{c}\text { Spill-over } \\
\text { (Yes/No) }\end{array}$ & RESULT \\
\hline SOY OIL( -1) & 1.000164 & 0.0000 & - & Mean \\
\hline Std Residuals : Crude & -0.000737 & 0.7401 & NO & Spill - \\
\hline Std Residuals : PALM Oil & 0.009646 & 0.0001 & YES $^{\wedge}$ & over \\
\hline Std Residuals : RS Oil & 0.012274 & 0.0000 & YES$^{\wedge}$ & w.r.t \\
\hline Std Residuals : SF Oil & 0.010096 & 0.0001 & YES $^{\wedge}$ & Soy Oil \\
\hline & & & & Palm Oil \\
\hline VARIANCE EQUATION & & & & \&RS Oil \\
\hline Std Residuals SQR : Crude & $-1.35 E-06$ & 0.9656 & NO & Variance \\
\hline Std Residuals SQR : PALM Oil & $-1.65 E-05$ & 0.6594 & NO & Over \\
\hline Std Residuals SQR : RS Oil & $-5.36 E-05$ & 0.2083 & NO & w.r.t \\
\hline Std Residuals SQR : SF Oil & $2.89 E-05$ & 0.0039 & YES^ & SF Oil \\
\hline
\end{tabular}

Appendix V (e) Spill-over from other variables to Sun Flower- Oil

\begin{tabular}{|c|c|c|c|c|}
\hline \multicolumn{5}{|c|}{ DEPENDENT VARIABLE : SF (SUNFLOWER OIL) } \\
\hline MEAN EQUATION & $\begin{array}{c}\text { Beta } \\
\text { Coefficient }\end{array}$ & \multicolumn{1}{|l|}{$\mathbf{p}^{\prime}$ value } & $\begin{array}{c}\text { Spill-over } \\
\text { (Yes/No) }\end{array}$ & RESULT \\
\hline SF OIL(-1) & 1.000149 & 0.0000 & - & Mean \\
\hline Std Residuals : Crude & -0.003782 & 0.4532 & NO & Spill - \\
\hline Std Residuals : PALM Oil & 0.005844 & 0.4118 & NO & over \\
\hline Std Residuals : RS Oil & 0.005965 & 0.4385 & NO & w.r.t \\
\hline Std Residuals : SOY Oil & 0.017089 & 0.0377 & YES^ & Soy Oil \\
\hline & & & & and \\
\hline VARIANCE EQUATION & & & & Variance \\
\hline Std Residuals SQR : Crude & $-9.48 E-05$ & 0.0966 & YES@ & Over \\
\hline Std Residuals SQR : PALM Oil & $-5.09 E-05$ & 0.6282 & NO & w.r.t \\
\hline Std Residuals SQR : RS Oil & $-5.50 E-05$ & 0.6894 & NO & Crude \\
\hline Std Residuals SQR : SOY Oil & -0.000108 & 0.4626 & NO & \\
\hline
\end{tabular}

